\title{
Geopolymeric repair mortars based on a low reactive clay
}

Walid Tahri ${ }^{1}$, Basma Samet ${ }^{1}$, Fernando Pacheco-Torgal' ${ }^{2}$, José Aguiar ${ }^{2}$ and Samir Baklouti ${ }^{\top}$

${ }^{1}$ University of Sfax, Sfax, Tunisie, ${ }^{2}$ University of Minho, Guimarães, Portugal

\subsection{Introduction}

Worldwide infrastructure rehabilitation costs are staggering. The patch repair method is widely used to restore the original conditions of the concrete structures (Emmons and Vaysburd, 1994, 1996). Most patch repair mortars fall into two categories: mortars based on organic binders (epoxy resin or polyester) or those based on inorganic binders, like Portland cement (PC). The former are associated with toxic side effects (Pacheco-Torgal et al., 2012b) while the latter are known for their high embodied carbon (Pacheco-Torgal et al., 2013). Geopolymers are novel inorganic binders with a high potential to replace PC-based ones (van Deventer et al., 2012). The geopolymerization of alumino-silicate materials is a complex chemical process involving the dissolution of raw materials, transportation or orientation, and polycondensation of the reaction products ( $\mathrm{Li}$ et al., 2010; Van Deventer et al., 2010; Provis, 2014; Pacheco-Torgal et al., 2016). Investigations in the field of geopolymers reveal a third category of mortars with potential to be used in the field of concrete patch repair (Pacheco-Torgal et al., 2012a). Some authors (Pacheco-Torgal et al., 2008a) have shown that concrete specimens repaired with geopolymeric mortar and one day curing have higher bond strength than specimens repaired with current commercial repair products after 28 days curing. This is a promising performance because adhesion to the concrete substrate is a crucial property of the repair mortars (Khan et al., 2012). This chapter presents results of an investigation concerning the development of geopolymeric repair mortars based on a low reactive, calcined clay. The influence of replacing small amounts of calcined clay with fly ash (FA) and metakaolin (MK) was also studied.

\subsection{Experimental work}

\subsubsection{Materials}

The clay materials used originate from Medenine Region of Tunisia. Previous studies performed on many clay materials showed that kaolinite is the major mineral and quartz the major impurity. The dried clay fractions were crushed in 
a mortar and then sieved to $100 \mu \mathrm{m}$. The clay fractions were calcined in a programmable electric furnace (Nabertherm, Mod.LH 60/14) for 6 hours at a heating rate of $11.33^{\circ} \mathrm{C} / \mathrm{min}$ at a temperature of $700^{\circ} \mathrm{C}$ (Essaidi et al., 2014). Results of the chemical composition of the clay fractions are given in Table 12.1. Fig. 12.1 presents the X-ray diffractograms (XRD) of the natural clay (NC). The basic clay mineral in the clay fractions is kaolinite, associated to quartz and illite. Minor amounts of gypsum and hematite can be considered as impurities. Quantitatively, the diffractogram confirms that this clay has lower kaolinite content. The characteristic peaks of illite $\left(8.8,18.8\right.$, and $\left.19.9^{\circ} \mathrm{C}\right)$ can be observed. The overall result shows that the thermal treatment of the clay fractions at $700^{\circ} \mathrm{C}$ is enough to transform kaolinite into metakaolinite. This is in agreement with the thermal analyses-differential scanning calorimetry (DSC) and thermogravimetric (TG) - results, which show that the dehydroxylation of kaolinite starts from around $480^{\circ} \mathrm{C}$. In the X-ray diffraction patterns of the calcined clay, the disappearance of the kaolin peaks and their change to metakaolinite was observed. After calcination, the kaolinite disappeared but some traces of illite remained almost intact. However, after calcination gypsum was transformed into anhydrite. Fig. 12.2, presents DSC and TG curves of the clay fractions of NC. The thermal behavior, typical of kaolinite clays is displayed (Mackenzie, 1957; Bouaziz and Rollet, 1972). The interval $\left(20-120^{\circ} \mathrm{C}\right)$ showed the period of drying the raw material, which consisted of the disappearance of the water molecules. From 400 to $500^{\circ} \mathrm{C}$, the kaolinite changed into the new metakaolinite phase. Between 600 and $800^{\circ} \mathrm{C}$, calcite also decomposed, generating $\mathrm{CO}_{2}$. The SEM analysis (Fig. 12.3) shows the morphology of the raw material, which consisted of major mineral clay kaolinite layers. This transformation of kaolinite into metakaolinite produces a more reactive material. This result was confirmed by the infrared spectra of the raw material NC (Fig. 12.4), in which some absorption bands characteristic of kaolinite are present $\left(3693-3619 \mathrm{~cm}^{-1}\right.$ ) (Kakali et al., 2001).

\section{Table 12.1 Chemical composition of the natural clay (NC) fractions}

\begin{tabular}{|l|l|}
\hline \multicolumn{2}{|l|}{ Raw material (clay, NC) } \\
\hline Oxides & Weight (\%) \\
\hline $\mathrm{SiO}_{2}$ & 60.80 \\
$\mathrm{Al}_{2} \mathrm{O}_{3}$ & 16.20 \\
$\mathrm{CaO}$ & 2.15 \\
$\mathrm{~F}_{2} \mathrm{O}_{3}$ & 5.87 \\
$\mathrm{SO}_{3}$ & 0.08 \\
$\mathrm{~K}_{2} \mathrm{O}_{3}$ & 2.71 \\
$\mathrm{MgO} \mathrm{Na}$ & 2.38 \\
$\mathrm{Na}_{2}$ & 0.003 \\
$\mathrm{PF}$ & 9.16 \\
\hline
\end{tabular}




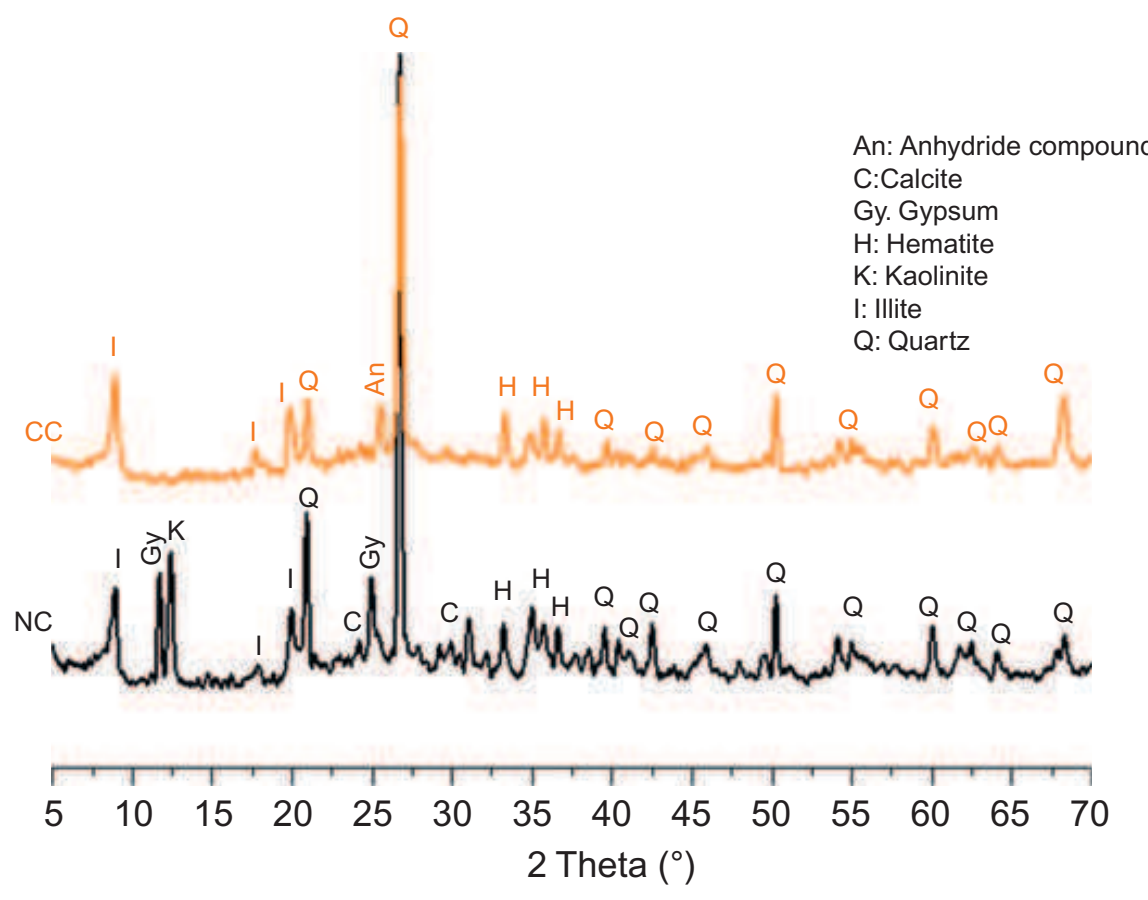

Figure 12.1 X-ray diffractograms of the raw material natural clay (NC) and calcined clay at $700^{\circ} \mathrm{C}(\mathrm{CC})$.

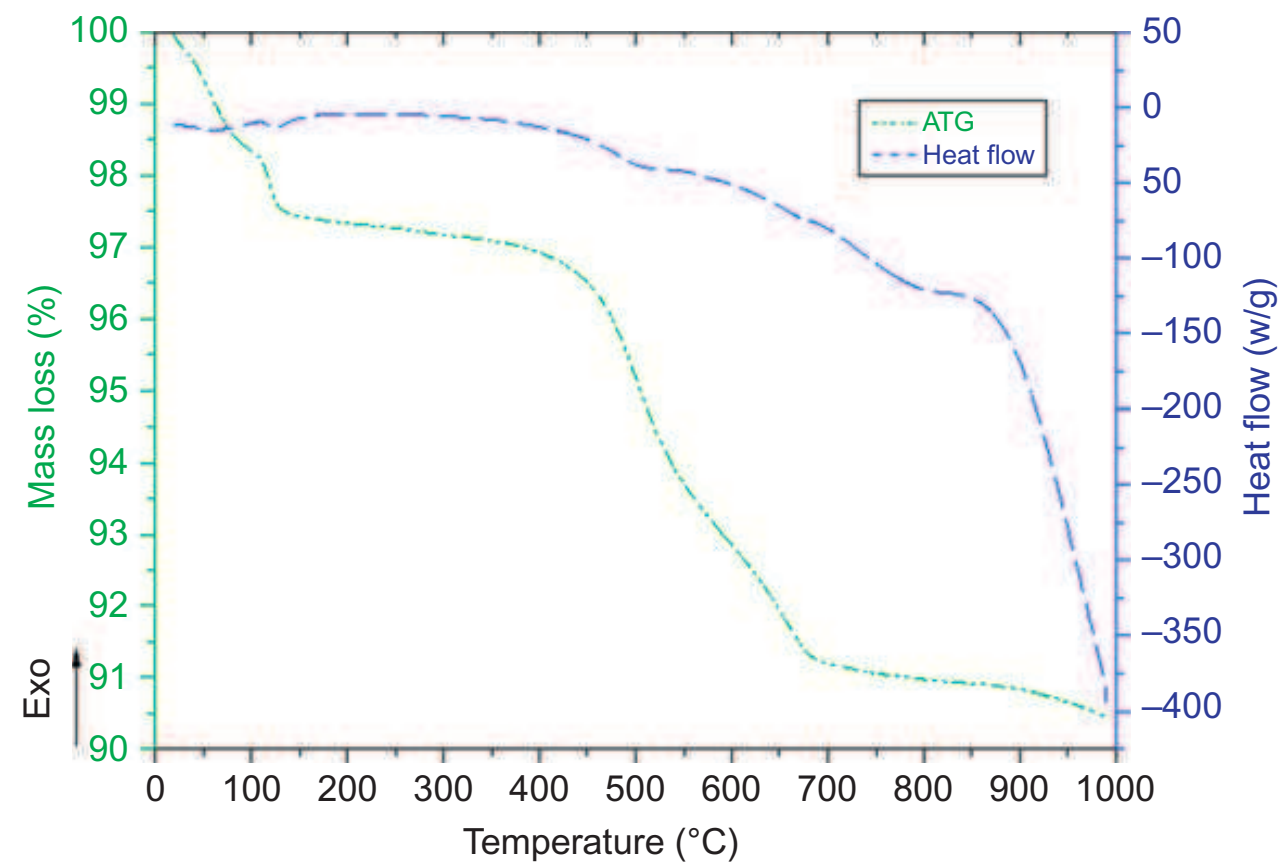

Figure 12.2 Thermo-gravimetric analysis/differential scanning calorimetry (TGA/DSC) of natural clay $(\mathrm{NC})$.

\subsubsection{Mix proportioning and synthesis}

The alkaline solution used was a mixture of an aqueous solution of sodium hydroxide $12 \mathrm{M}$ and sodium silicate, with a bulk density of $1350 \mathrm{~kg} / \mathrm{m}^{3}$ and 

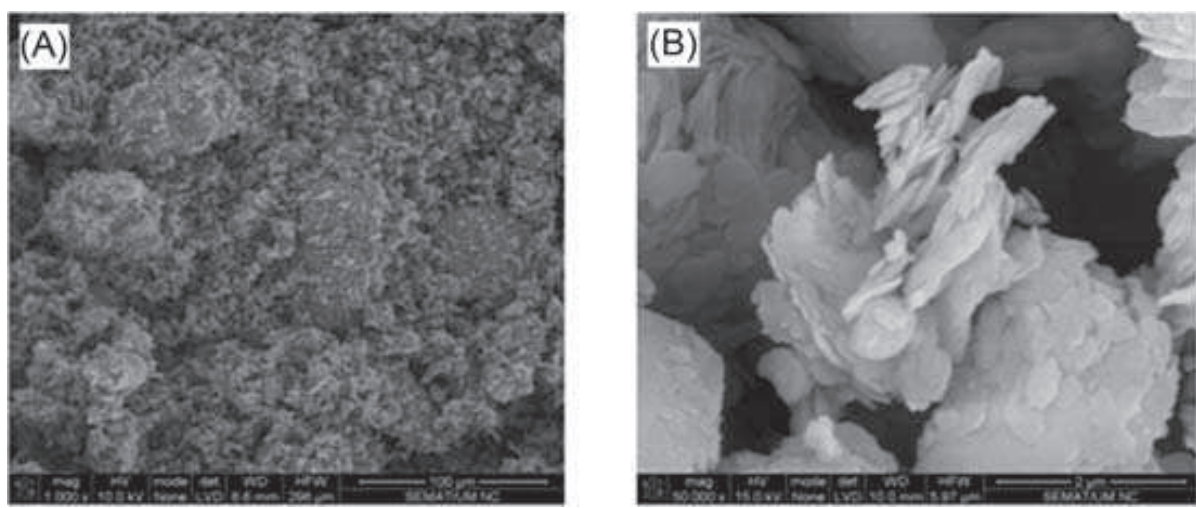

Figure 12.3 Morphology of the natural clay (NC): (A) Before calcination; (B) After calcination.

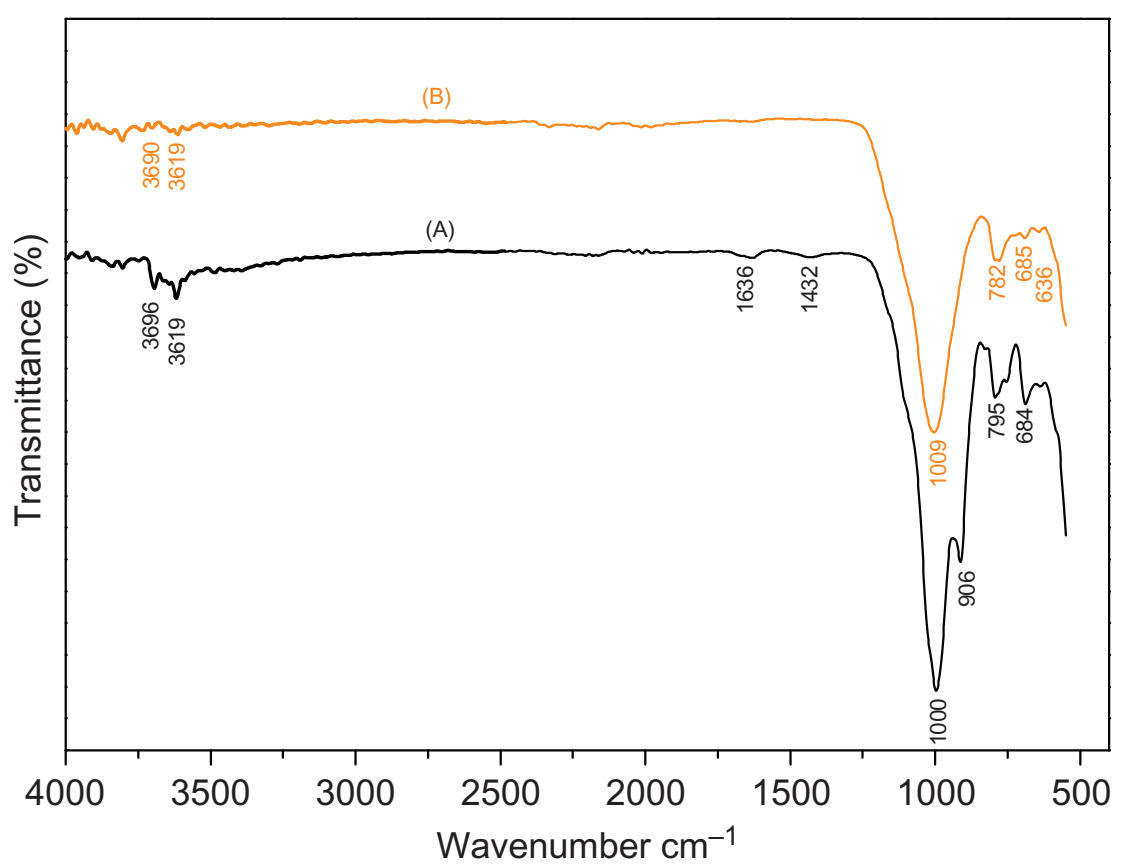

Figure 12.4 Fourier transform infrared (FTIR) spectra of raw material: (A) to natural clay (NC) and (B) calcined clay (CC).

ratio: $\mathrm{Na}_{2} \mathrm{SiO}_{3} / \mathrm{NaOH}=2.5$. The sodium hydroxide solution was obtained by dissolving dried pellets of $99 \%$ purity in distilled water. The sodium silicate solution had a composition by weight of $\mathrm{Na}_{2}\left(\mathrm{SiO}_{2}\right)_{\underline{x}} \cdot y\left(\mathrm{H}_{2} \mathrm{O}\right)$ in which $3.19 \leq \underline{x} \leq 3.53$ and $50 \% \leq y \leq 60 \%$. The geopolymer mortar consisted of a mixture of the alkaline solution, powdered calcined clay, calcium hydroxide and sand. The sand has a maximum dimension of $4 \mathrm{~mm}$ and a density of $2660 \mathrm{~kg} / \mathrm{m}^{3}$. The calcium hydroxide had more than $70 \%$ of $\mathrm{CaO}$ and a density of $460 \mathrm{~kg} / \mathrm{m}^{3}$. Several authors have shown that the use of minor amounts of calcium hydroxide is crucial for the strength and durability of geopolymers (Lee and Van Deventer, 2002; Yip et al., 2005; PachecoTorgal et al., 2008b; van Deventer et al., 2012). The assembly was mixed in a Hobart mixer ( $\mathrm{M} \& \mathrm{O}$, model N50-G) for 3 minutes. The sample of geopolymer mortar was vibrated in the vibrating table to remove entrapped air bubbles. During 
the hardening of the geopolymer samples, the molds were covered with a thin plastic film to avoid water evaporation and then kept for 24 hours at the ambient atmosphere of the laboratory $\left(24-26^{\circ} \mathrm{C}\right)$. After measurement of the compressive strength, certain fragments of geopolymer mortar samples were kept for XRD, FTIR, TGA, DSC, and SEM analyses. Table 12.2 shows the composition of the geopolymeric mortars. In a second phase, a new set of six mixtures was prepared, based on G1R3, containing $80 \%$ of the initial activator/binder ratio and with a partial replacement of Tunisian clay by FA and MK (Table 12.3). The compositions of MK and FA are presented in Table 12.4.

\subsubsection{Workability}

The workability assessment has been conducted with a truncated conical mold and a jolting table, according to the standard EN 1015-3.

\subsubsection{Unrestrained shrinkage}

Unrestrained shrinkage was determined according to LNEC E398-1993 standard. The specimens were removed from the molds 24 hours after being mixed and placed, then were wrapped with Perspex paper. Other authors used aluminum paper, having reported the formation of hydrogen gas bubbles due to a reaction between the aluminum and the alkalis from the mortar (Pacheco-Torgal et al., 2008c). The measurement of shrinkage was carried out on hardened geopolymer mortar samples aged at $1,7,14$, and 18 days respectively.

\subsubsection{Compressive strength testing}

Compressive strength data was obtained according to EN 1015-11 standard. The fresh mortar was cast and allowed to set at room temperature for 24 hours before being removed from the molds and kept at room temperature $\left(20^{\circ} \mathrm{C}\right)$ until being tested. Compressive strength for each mortar mixture was obtained from an average of three specimens. The compressive strength was determined on the hardened geopolymer mortar samples, aged of 28 days using an electrohydraulic press $(\mathrm{M} \& \mathrm{O}$, type $11.50, \mathrm{~N}^{\circ} 21$ ) at an average rate of $3 \mathrm{~mm} / \mathrm{min}$.

\section{Table 12.2 Mixture quantities-first phase}

\begin{tabular}{|c|c|c|c|c|c|c|}
\hline \multicolumn{7}{|c|}{ Materials } \\
\hline \multirow[b]{2}{*}{ Mixtures } & \multirow{2}{*}{$\begin{array}{l}\text { Calcined } \\
\text { clay }(g)\end{array}$} & \multirow{2}{*}{$\begin{array}{l}\text { Lime } \\
\text { (g) }\end{array}$} & \multirow{2}{*}{$\begin{array}{l}\text { Sand } \\
(\mathrm{g})\end{array}$} & \multicolumn{2}{|c|}{ Activator (g) } & \multirow{2}{*}{$\begin{array}{c}\text { (Lime }+ \text { Calcined } \\
\text { clay)/sand }\end{array}$} \\
\hline & & & & $\mathrm{Na}_{2} \mathrm{SiO}_{3}$ & $\mathrm{NaOH}$ & \\
\hline G1R2 & 674 & 74.8 & 1496 & 535 & 213 & $1: 2$ \\
\hline G1R3 & 674 & 74.8 & 2250 & 535 & 213 & $1: 3$ \\
\hline G1R4 & 674 & 74.8 & 2992 & 535 & 213 & $1: 4$ \\
\hline
\end{tabular}


Table 12.3 Mixture quantities—second phase

\begin{tabular}{|c|c|c|c|c|c|c|c|c|c|c|c|}
\hline \multirow[b]{2}{*}{ Mixtures } & \multirow{2}{*}{$\begin{array}{l}\text { Calcined } \\
\text { clay (g) }\end{array}$} & \multirow{2}{*}{$\begin{array}{l}\text { Lime } \\
\text { (g) }\end{array}$} & \multirow{2}{*}{$\begin{array}{l}\text { Sand } \\
\text { (g) }\end{array}$} & \multicolumn{2}{|c|}{ Activator (g) } & \multirow{2}{*}{$\begin{array}{l}\text { FA } \\
(\mathrm{g})\end{array}$} & \multirow{2}{*}{$\begin{array}{l}\text { FA } \\
(\%)\end{array}$} & \multirow{2}{*}{$\begin{array}{l}\text { Mk } \\
(\mathrm{g})\end{array}$} & \multirow{2}{*}{$\begin{array}{l}\text { Mk } \\
(\%)\end{array}$} & \multirow{2}{*}{$\begin{array}{l}\text { Mass } \\
\text { ratio }_{\text {Agr }}= \\
(\text { Lime + Clay }) / \\
\text { sand }\end{array}$} & \multirow{2}{*}{$\begin{array}{l}\text { Mass } \\
\text { ratio }_{\text {Act }}= \\
\mathrm{Na}_{2} \mathrm{SiO}_{3} / \\
\mathrm{NaOH}\end{array}$} \\
\hline & & & & $\mathrm{Na}_{2} \mathrm{SiO}_{3}$ & $\mathrm{NaOH}$ & & & & & & \\
\hline $\begin{array}{c}\text { G1R.3_80\% } \\
\text { _REF }\end{array}$ & 1264.79 & 140.53 & 4215.97 & 801.97 & 322.29 & 0 & - & 0 & - & $1: 3$ & 2,5 \\
\hline $\begin{array}{r}\text { G1R3_80\% } \\
\quad 10 \% \mathrm{FA}\end{array}$ & 1138.31 & 140.53 & 4215.97 & 801.97 & 322.29 & 126.48 & 10 & 0 & - & & \\
\hline $\begin{array}{r}\text { G1R3_80\% } \\
\quad 10 \% \mathrm{Mk}\end{array}$ & 1138,31 & 140.53 & 4215.97 & 801.97 & 322.29 & 0 & - & 126.48 & 10 & & \\
\hline $\begin{array}{r}\text { G1R3_80\% } \\
\quad 15 \% \mathrm{Mk}\end{array}$ & 1075.07 & 140.53 & 4215.97 & 801.97 & 322.29 & 0 & - & 189.72 & 15 & & \\
\hline $\begin{array}{r}\text { G1R3_80\% } \\
30 \% \mathrm{Mk}\end{array}$ & 885.35 & 140.53 & 4215.97 & 801.97 & 322.29 & 0 & - & 379.44 & 30 & & \\
\hline
\end{tabular}

MK, metakaolin; FA, fly ash. 


\section{Table 12.4 Chemical composition of metakaolin (MK) and fly ash} (FA)

\begin{tabular}{|c|c|c|}
\hline Constituents (\%) & MK & FA \\
\hline $\mathrm{SiO}_{2}$ & 61.26 & 49.12 \\
\hline $\mathrm{Al}_{2} \mathrm{O}_{3}$ & 27.0 & 27.3 \\
\hline $\mathrm{Fe}_{2} \mathrm{O}_{3}$ & 3.08 & 8.19 \\
\hline $\mathrm{CaO}$ & 0.159 & 2.36 \\
\hline $\mathrm{MgO}$ & 0.161 & 1.42 \\
\hline $\mathrm{Na}_{2} \mathrm{O}$ & 0.096 & 0.99 \\
\hline $\mathrm{K}_{2} \mathrm{O}$ & 6.622 & 3.34 \\
\hline $\mathrm{SO}_{3}$ & 0.048 & - \\
\hline $\mathrm{TiO}_{2}$ & 0.994 & 2.32 \\
\hline $\mathrm{P}_{2} \mathrm{O}_{5}$ & 0.325 & - \\
\hline $\mathrm{Zn}$ & 0.005 & - \\
\hline $\mathrm{ZrO}_{2}$ & 0.056 & - \\
\hline Other oxides & 0.255 & \\
\hline
\end{tabular}

\subsubsection{Modulus of elasticity}

The modulus of elasticity was determined using cylindrical samples with a diameter of $50 \mathrm{~mm}$ and a length of $100 \mathrm{~mm}$. These specimens were tested after the established curing time of 28 days. The values of the modulus of elasticity were obtained from the average of the three specimens.

\subsubsection{Adhesion strength and flexural strength of Portland cement concrete rehabilitated beams}

Bond strength is one of the most important properties of concrete repair materials. Bond strength depends on the repair material characteristics and on the roughness of the concrete substrate surface. In this investigation, the Pull-off test was used to assess this property. This test was done according to the standard BS EN 1542 (1999). A $20 \mathrm{MPa}$ compressive strength was used as substrate (Table 12.5) and a geopolymeric mortar layer was cast over the concrete substrate. A circular hole (50 $\mathrm{mm}$ diameter and $60 \mathrm{~mm}$ in depth) was then cut through the mortar layer. Afterwards, several metallic discs were glued with epoxy resin to the geopolymeric mortar. The Pull-off machine (Proceq Dyna Z15 device) was attached to the metallic discs, allowing for the assessment of the adhesion strength until rupture. Additionally, several concrete beams, with the same composition of the Pull-Off substrates (Table 12.5) and with dimensions of $100 \times 100 \times 1000 \mathrm{~mm}^{3}$, were water-cured during 28 days until they were tested for flexural strength. 


\section{Table 12.5 Composition of the Portland cement (PC)} concrete substrate used in the Pull-off test $\left(\mathrm{kg} / \mathrm{m}^{3}\right)$

\begin{tabular}{|l|l|}
\hline Components & Mix \\
\hline Cement II 32.5 & $400 \mathrm{~kg}$ \\
Fine river sand & $578 \mathrm{~kg}$ \\
Coarse aggregate & $1066 \mathrm{~kg}$ \\
W/C ratio & $0.53 \mathrm{~kg}$ \\
Fc 28 days (MPa) & 20.3 \\
\hline
\end{tabular}
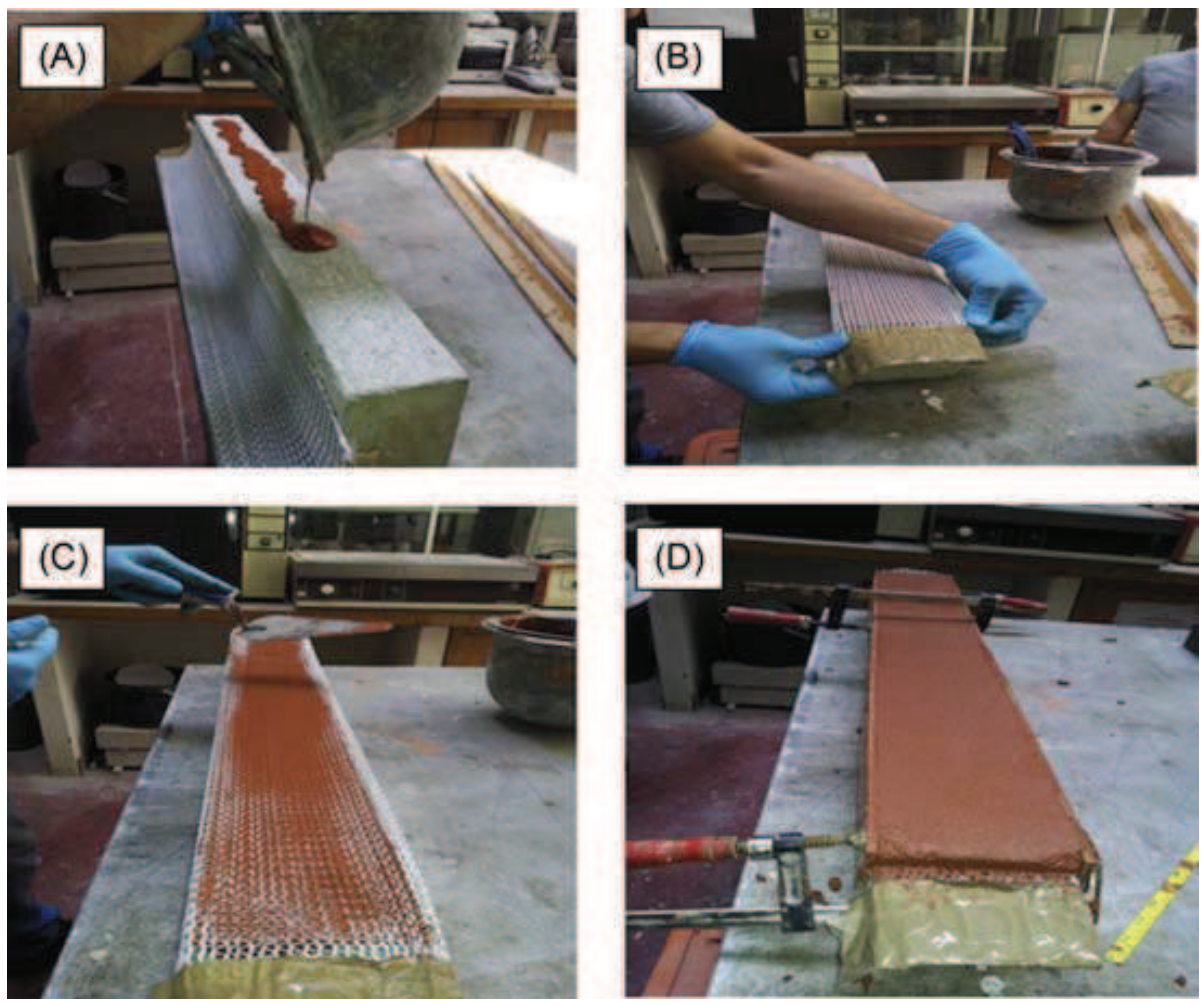

Figure 12.5 Portland cement (PC) concrete rehabilitated beams preparation: (A) placement of a geopolymeric primer; (B) placement of the metallic grid; (C) covering the metallic grid with geopolymeric mortar; (D) concluded beam.

The concrete beams were rehabilitated with a metallic grid and geopolymeric mortars (Fig. 12.5).

\subsubsection{Fourier transform infrared}

The FTIR spectra were acquired in the attenuated total reflectance (ATR) mode, between 4000 and $550 \mathrm{~cm}^{-1}$, using a Perkin Elmer FTIR Spectrum BX with an ATR PIKE MIRacle. The specimens for FTIR study were prepared by mixing $1 \mathrm{mg}$ of sample in $100 \mathrm{mg}$ of $\mathrm{KBr}$. Spectral analysis was performed over the range $4000-400 \mathrm{~cm}^{-1}$ at a resolution of $4 \mathrm{~cm}^{-1}$ 


\subsubsection{Scanning electron microscopy}

Scanning electron microscopy (SEM) was carried out using a Phillip XL 30 on pellets from hardened geopolymer samples aged at 28 days.

\subsection{Results and discussion}

\subsubsection{Workability}

The investigations showed that the flow diameter for the three mixtures decreases when the sand mass increases. The mixture with a binder/sand ratio of 1:2 has an excessive flow $(23 \mathrm{~cm})$, while the mixture with a binder/sand ratio of 1:3 has a flow currently found in most mortars $(180 \mathrm{~mm})$. The mixture with a binder/sand ratio of 1:4 seems to has a low flow diameter. However, it is acceptable when using the hand placement technique in which higher flows are not desirable, in order to avoid detachment risks.

\subsubsection{Unrestrained shrinkage}

The results of this test are shown in Fig. 12.6. In the first 2 days, the shrinkage increases very rapidly. Since the tests have been carried out with the isolation of specimens under a perspex film to avoid the evaporation of water, the measured shrinkage is the due to the hydration reaction (autogenous shrinkage). Consequently, the rapid increase in the first two days is relative to the capillary tensions within the gel framework during geopolymerization (Brinker and Scherrer 1990). Other authors (Teixeira-Pinto, 2004) that used alkali-activated MK-based binders in similar experimental conditions reported shrinkage results between 500 and 840 microstrain. Since mortars used in PC patch repair require very low shrinkage (Cusson, 2009) this means that those geopolymeric mortar mixtures show an unacceptable performance. Fig. 12.7 shows the unrestrained shrinkage of the second

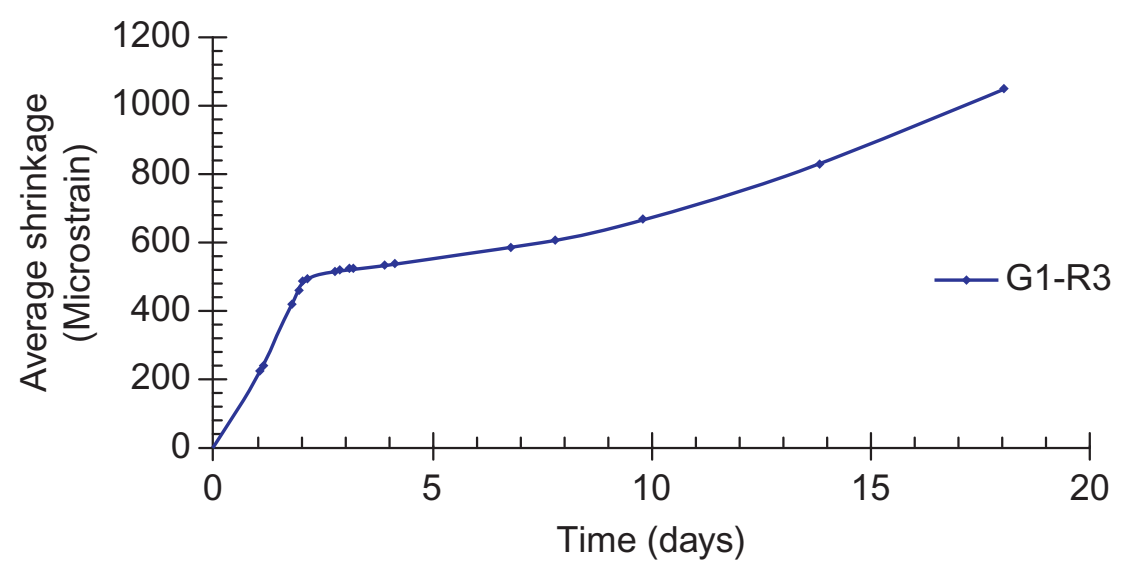

Figure 12.6 Shrinkage of the mixture with a binder/sand ratio of 1:3 as function of curing time (days). 


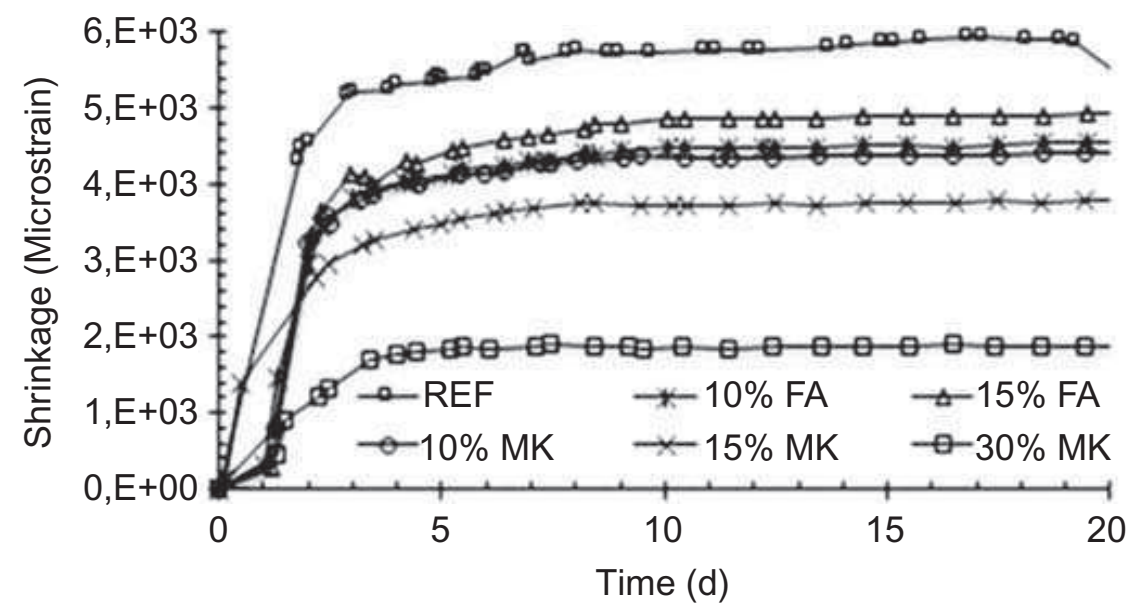

Figure 12.7 Unrestrained shrinkage of the modified G1R3 geopolymer mixture as function of curing time (days).

set of mixtures. The maximum unrestrained shrinkage is of $\sim 500-600$ microstrain and is due to the reduction of the alkaline activator. The partial replacement of Tunisian clay by FA also leads to a lower unrestrained shrinkage performance than the reference mixture. Partial replacement by MK outperforms FA-based mixtures. The comparison of the unrestrained shrinkage in 15\% FA mortar and in $15 \% \mathrm{MK}$ shows a very relevant difference. When $30 \% \mathrm{MK}$ is used, the observed unrestrained shrinkage is very low. This means that the new geopolymeric mortar mixtures based on the partial replacement of Tunisian clay by MK have an acceptable performance concerning this parameter.

\subsubsection{Compressive strength}

Fig. 12.8 shows the compressive strength results at 28 days curing. Although it seems that the compressive strength is influenced by the sand/binder mass ratio, the differences are very slight and fall within the standard deviation interval. The compressive strength at 28 days curing is below typical compressive strength of old PC reinforced concrete structures, in which 20-30 MPa can be expected, thus meaning that repair mortars should have a strength of at least $30 \mathrm{MPa}$. Other authors (Pacheco-Torgal et al., 2011) analyzed mortars with the same activator/binder ratio and the same $12 \mathrm{M}$ sodium hydroxide concentration obtaining a $40 \mathrm{MPa}$ compressive strength just after 7 days curing. However, they used MK as a binder, which is much more reactive than the calcined Tunisian clay used in this investigation. Mixtures with a small replacement of calcined Tunisian clay by MK should also be analyzed for compressive strength. Fig. 12.9 shows the compressive strength of the second set of mixtures. The results show that the partial replacement of Tunisian clay by $10 \%$ or even $15 \%$ of FA is not advantageous for 28 days compressive strength. The same occurs for flexural strength, although the $15 \%$ FA mixture shows a minor increase when compared to the reference mixture. This behavior is related to the low reactivity of FA. In the geopolymeric mixtures in which the Tunisian clay was partially replaced by MK, an increase in compressive strength is 


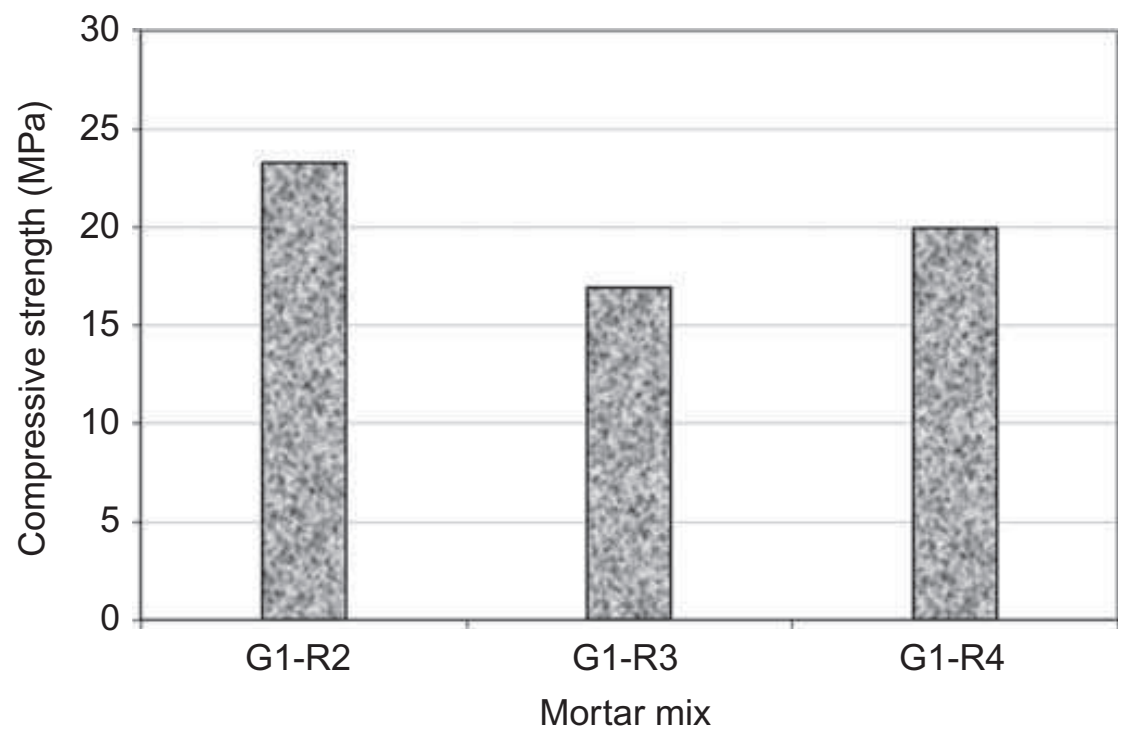

Figure 12.8 Compressive strength for geopolymeric mortar mixtures with sodium hydroxide concentrations $(12 \mathrm{M})$ and sand/binder mass ratios $(R=2 ; R=3, R=4)$.

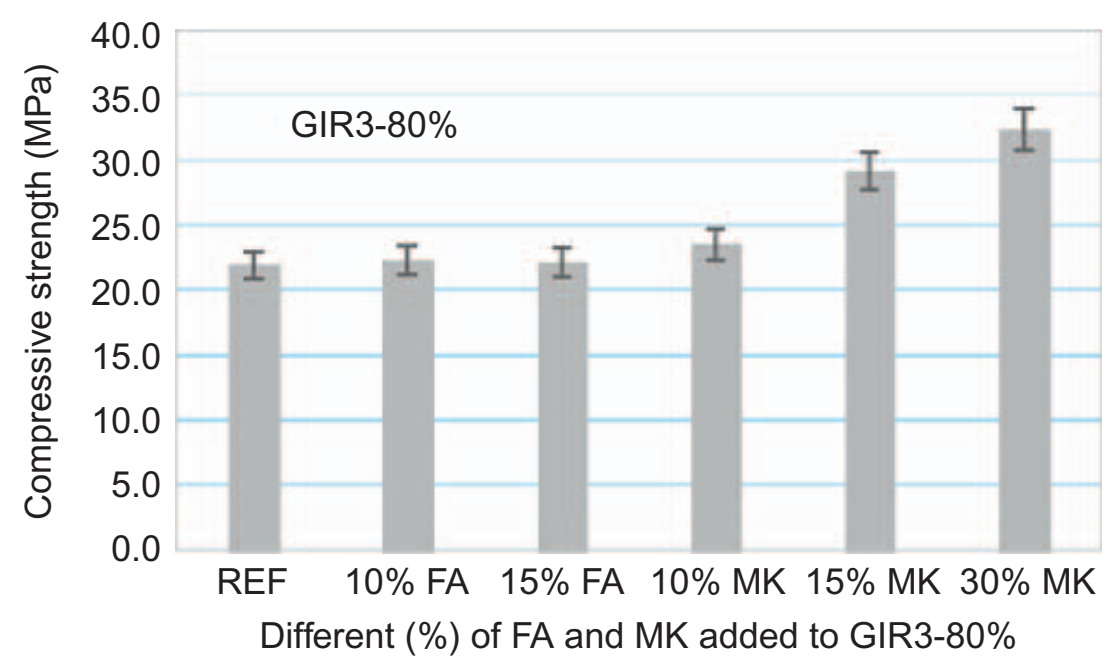

Figure 12.9 Compressive strength of the modified G1R3 geopolymer mixture.

visible only for $15 \%$ and $30 \%$. The replacement of Tunisian clays by $15 \%$ and $30 \%$ MK allows for compressive strengths around $30 \mathrm{MPa}$, which are typical of old PC reinforced concrete structures and constitute an important compressive strength requirement for repair mortars.

\subsubsection{Modulus of elasticity}

The modulus of elasticity of the mixtures with a binder/sand ratios of 1:3 and 1:4 are 1 and $0.82 \mathrm{GPa}$, respectively. Although these values are very different from typical PC-based binders, they bear some resemblance with the ones reported by other authors for the same compressive strength (Duxson et al., 2005, 2006). The modulus of elasticity at 28 days curing is below the typical modulus of elasticity of 
Ordinary Portland Cement (OPC) reinforced concrete structures. For a concrete substrate with $25 \mathrm{MPa}$ compressive strength at 28 days and using the EN 1992-1-1 (2004) European code expression $E_{\mathrm{cm}}=22\left[\left(f_{\mathrm{cm}}\right) / 10\right]^{0.3}$ to predict modulus elasticity, one obtains a value of $29 \mathrm{GPa}$. Therefore, in order to meet structural compatibility requirements (Table 12.6) new mixtures with a modulus of elasticity around 29 GPa are needed. Fig. 12.10 shows the modulus of elasticity of the second set of mixtures. The results show that the modulus of elasticity increases slightly with the replacement of Tunisian clay by FA. This behavior is not influenced when the FA percentage increase from $10 \%$ to $15 \%$. A higher modulus of elasticity is associated with the replacement of Tunisian clay by MK. This behavior is partially related to the increase in the compressive strength.

\subsubsection{Adhesion strength and flexural strength of rehabilitated beams}

The results of the adhesion strength in the Pull-off test show that the geopolymeric mortar which contain 15\% FA replacement led to an increase of the adhesion strength by $\sim 40 \%$. The replacement of $30 \%$ calcined clay by MK leads to an adhesion strength increase of almost $80 \%$. Furthermore, experimental tests have shown that it takes a $40 \%$ replacement of the Tunisian clay by MK to reach the $0.8 \mathrm{MPa}$ threshold of adhesion strength for patch repair of reinforced concrete (Concrete Society, 1991). The flexural strength of the PC concrete beams rehabilitated with geopolymeric mortars is shown in Fig. 12.11. The concrete beams repaired with the

\section{Table 12.6 Structural compatibility_general requisites for repair mortars}

\begin{tabular}{|c|c|}
\hline Properties & $\begin{array}{l}\text { Relation between the repair mortar (Rp) and the } \\
\text { concrete substrate }(\mathrm{Cs})\end{array}$ \\
\hline $\begin{array}{l}\text { Strength in compression, } \\
\text { tension, and flexure }\end{array}$ & $\mathrm{Rp} \geq \mathrm{Cs}$ \\
\hline $\begin{array}{l}\text { Modulus in compression, } \\
\text { tension, and flexure }\end{array}$ & $\mathrm{Rp} \sim \mathrm{Cs}$ \\
\hline Poisson's ratio & Dependent on modulus and type of repair \\
\hline $\begin{array}{l}\text { Coefficient of thermal } \\
\text { expansion }\end{array}$ & $\mathrm{Rp} \sim \mathrm{Cs}$ \\
\hline $\begin{array}{l}\text { Adhesion in tension and in } \\
\text { shear }\end{array}$ & $\mathrm{Rp} \geq \mathrm{Cs}$ \\
\hline Curing and long-term shrinkage & $\mathrm{Rp} \geq \mathrm{Cs}$ \\
\hline Strain capacity & $\mathrm{Rp} \geq \mathrm{Cs}$ \\
\hline Creep & $\begin{array}{l}\text { Dependent on whether creep causes desirable or } \\
\text { undesirable effects }\end{array}$ \\
\hline Fatigue performance & $\mathrm{Rp} \geq \mathrm{Cs}$ \\
\hline
\end{tabular}

Source: From Morgan, D., 1996. Compatibility of concrete repair materials and systems. Constr. Build. Mater. 10 57-67. 


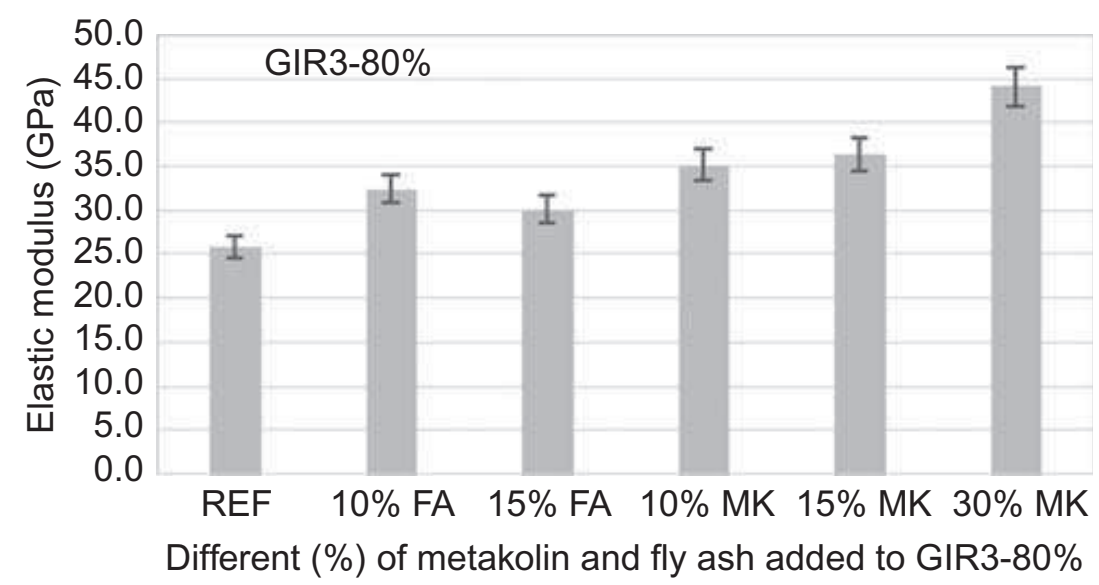

Figure 12.10 Modulus of elasticity of the modified G1R3 geopolymer mixtures.

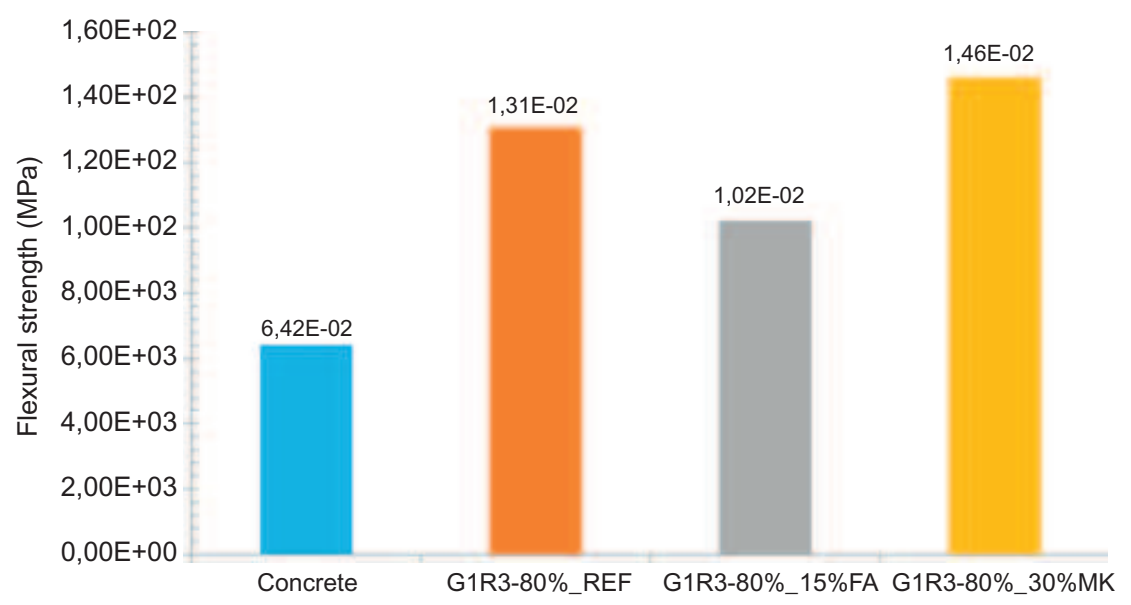

Figure 12.11 Flexural strength of the Portland cement (PC) concrete rehabilitated beams.

calcined clay and 30\% MK mortars show a flexural strength around $230 \%$ higher than plain concrete beams.

\subsubsection{Hydration products of mortars}

\subsubsection{Thermal analysis (TGA/DSC)}

Simultaneous thermo-gravimetric analysis (TGA) and DSC analyses were performed on three geopolymeric mortars (Fig. 12.12). In a temperature interval between 0 and $120^{\circ} \mathrm{C}$, the three TGA curves showed three similar weight losses. In this case, the phenomenon presented was the evaporation of the molecular water. These results were confirmed by the DSC curves, as the three endothermic peaks indicated the release of $\mathrm{H}_{2} \mathrm{O}$ in the mixture.

\subsubsection{X-ray diffractograms}

The XRD of the hardened geopolymer mortar are presented in Fig. 12.13. The XRDs show the presence of characteristic peaks of quartz and calcite $\mathrm{CaCO}_{3}$, which 

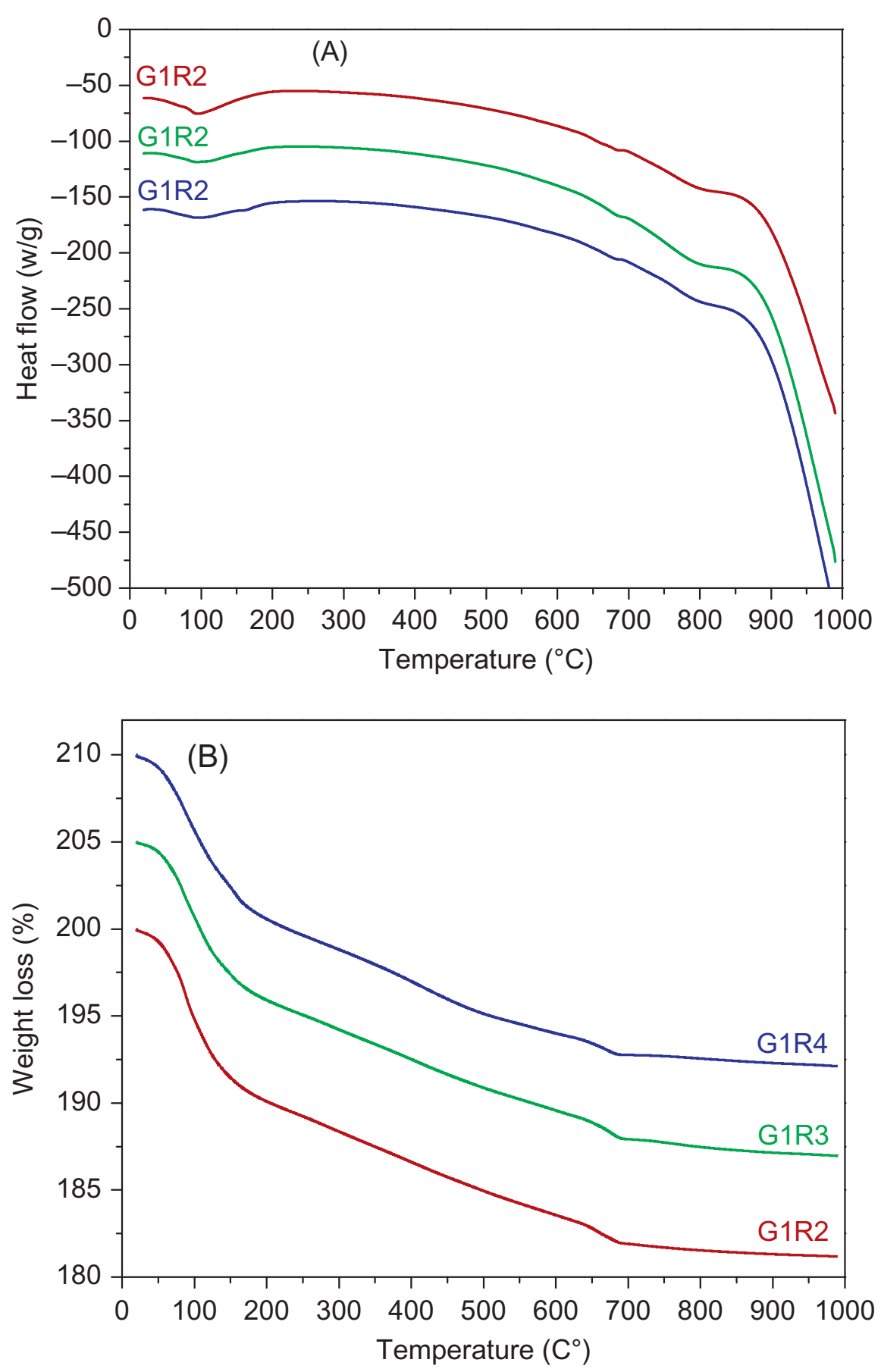

Figure 12.12 Thermo-gravimetric analysis/differential scanning calorimetry (TGA/DSC) data of geopolymer mortars: (A) DSC; (B) TGA.

means that these minerals are not dissolved during geopolymerization. In addition, a weak zeolite (analcime) appeared at $31^{\circ} \mathrm{C}$ in the spectrogram of the three geopolymeric mortars. This occurs in the same position of two theta with a small modification of intensity. These phases usually appear in geopolymer systems with a high water content. Too little or too much water content can hinder zeolite formation (Wang et al., 2005). Fig. 12.14 shows the XRD of geopolymers of G1R3 modified 


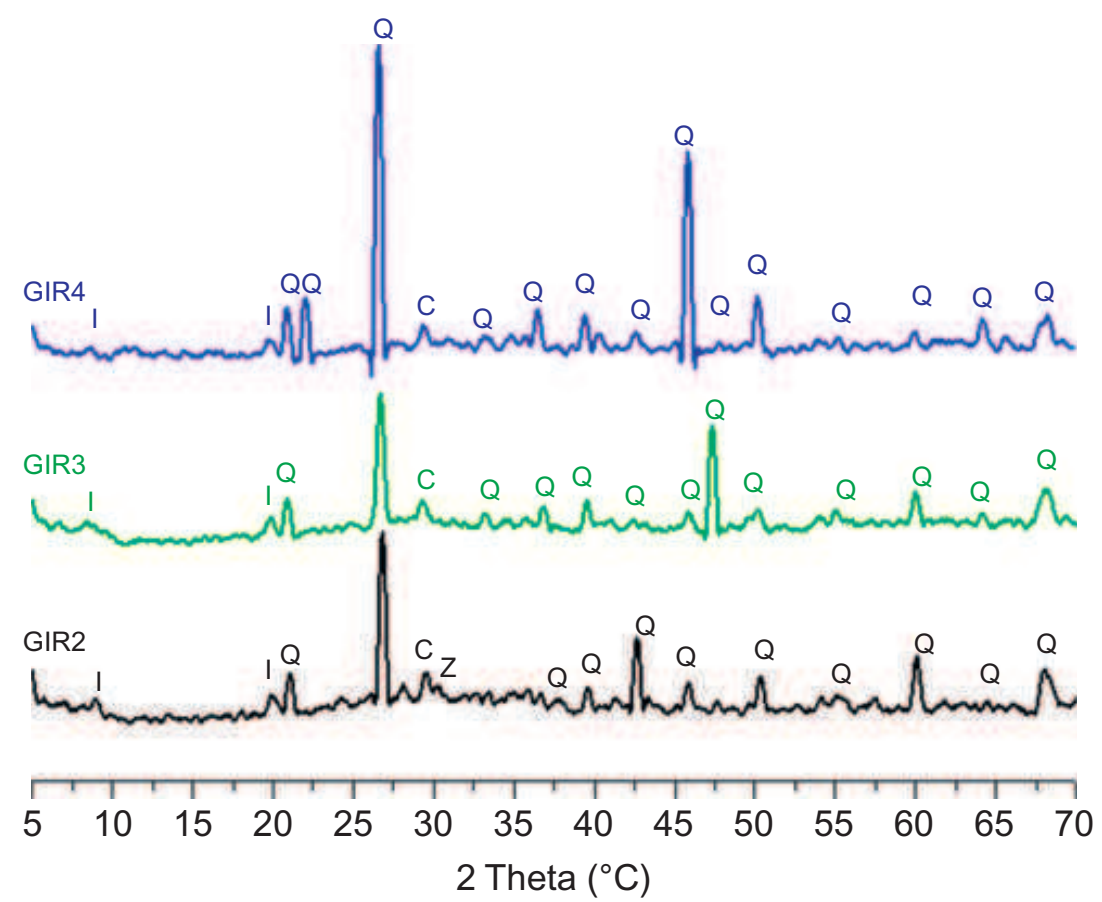

Figure 12.13 X-ray diffractograms of geopolymers I-Illite, Q-Quartz, C-Calcite, Z-Zeolite (G1R2, G1R3, G1R4).

mixtures. The mullite in the FA samples appears to have reacted entirely under the alkaline conditions.

\subsubsection{Fourier transform infrared spectra}

The Fourier transform infrared (FTIR) spectra of the hardened geopolymer mortar are presented in Fig. 12.15. Strong vibrations, typical of alluminosilicates can be observed. The peak centered around $975 \mathrm{~cm}^{-1}$, shifts to a lower value and this shift is characteristic of a geopolymerization reaction corresponding to the $\mathrm{Si}-\mathrm{O}-\mathrm{Al}$ and $\mathrm{Si}-\mathrm{O}-\mathrm{Si}$ vibration bands. The band at $\sim 870 \mathrm{~cm}^{-1}$ is assigned to $\mathrm{Si}-\mathrm{OH}$ bending vibration. $\mathrm{Al}-\mathrm{O}-\mathrm{Si}$ vibrations correspond to the absorption bands $600-800 \mathrm{~cm}^{-1}$. The absorption peak of $782 \mathrm{~cm}^{-1}$ was an indication of the presence of quartz (Lin et al., 2003). The absorption band around 1413 and $1433 \mathrm{~cm}^{-1}$ is attributed to stretching vibrations of $\mathrm{CO}_{3}{ }^{2-}$ ions, confirming the existence of carbonate species (Fernandez-Jimenez and Palomo, 2005). The decreasing in the $\mathrm{OH}$ bond may be also be due to the zeolites structure (crystalline phase) needing more water molecules than the minerals polymers (amorphous phase). Fig. 12.16 shows the FTIR spectra of geopolymers belonging to the G1R3 modified mixtures. All FTIR spectra developed in a single band located at 1000 and $1004 \mathrm{~cm}^{-1}$, corresponding to a region assigned for Si-O-Si (Lazarer, 1972; Nakamoto, 1997; Phair and van Deventer, 2002). The presence of the bands located at 776 and at $692 \mathrm{~cm}^{-1}$ are due to the quartz (Criado et al., 2007). The smalls bands appearing at $\sim 1420,1422$, and at $1489 \mathrm{~cm}^{-1}$ are related to the asymmetric stretching of the $\mathrm{O}-\mathrm{C}-\mathrm{O}$ bonds of $\mathrm{CO}_{3}{ }^{2-}$ due to atmospheric carbonation for all geopolymers mortars. 

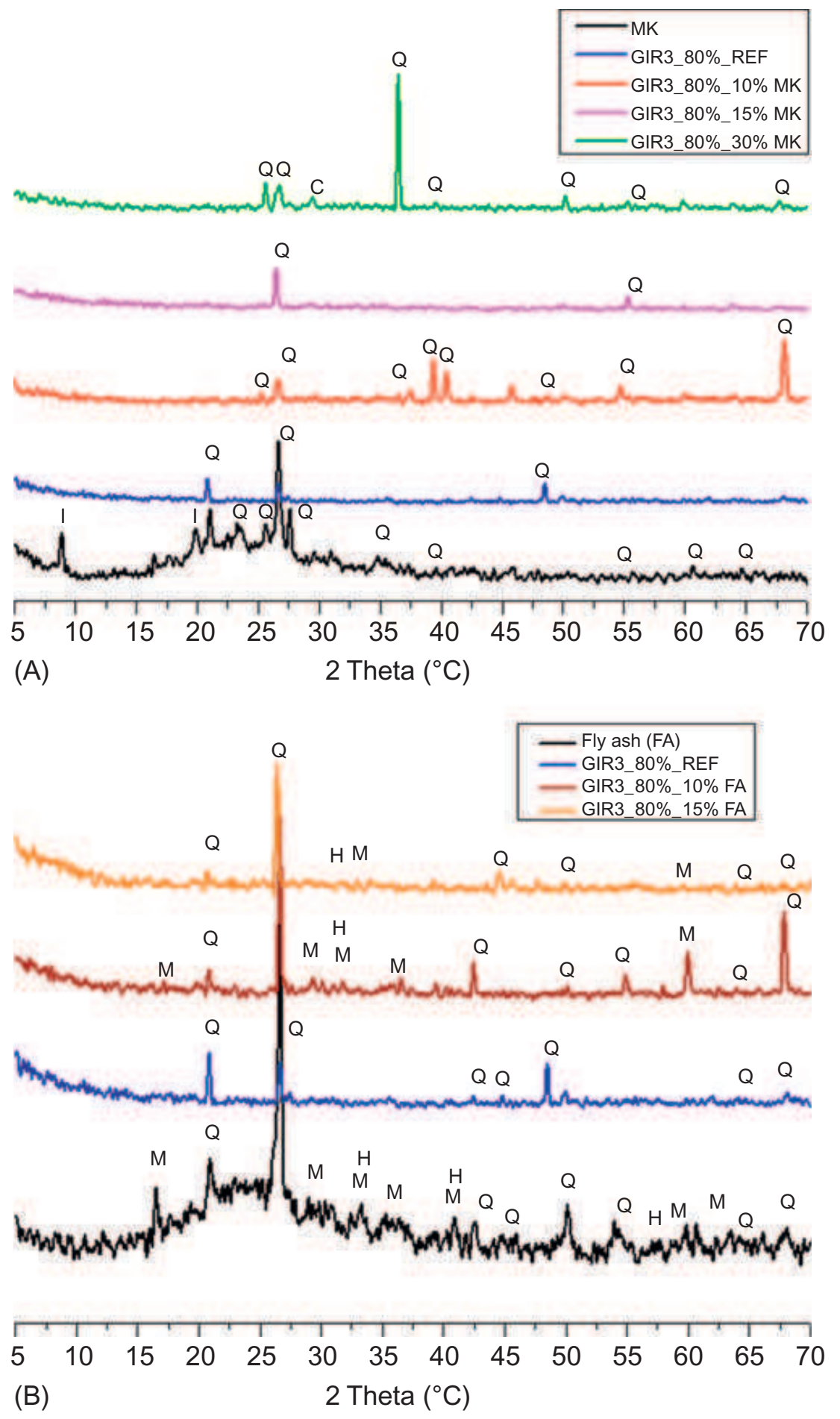

Figure 12.14 X-ray diffractograms of G1R3 modified geopolymeric mixtures: (Above) Metakaolin (MK) based; (Below) Fly ash (FA) based.

\subsubsection{Scanning Electron Microscopy}

SEM micrographs of the first-phase geopolymeric mortars are shown in Fig. 12.17. A homogeneous microstructure appears in all samples. Some visible cracks can be associated to the high autogenous shrinkage. Fig. 12.18 shows the microstructure of G1R3-modified mixtures. Several microcracks can be noticed, with the exception 


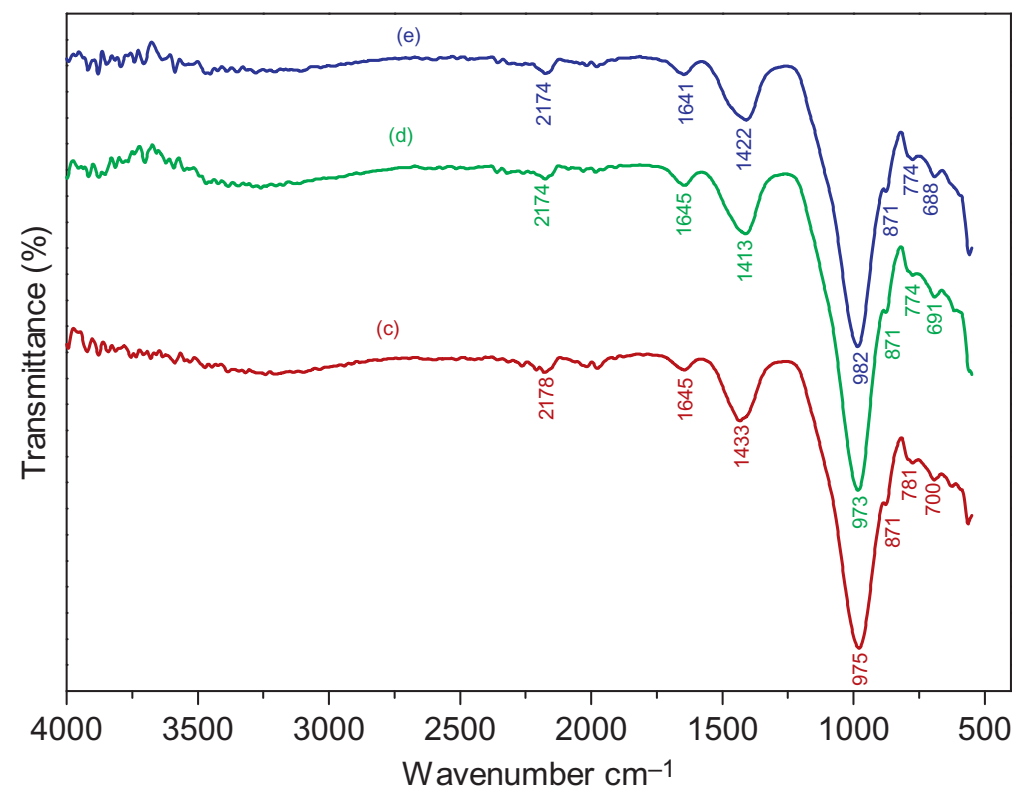

Figure 12.15 Fourier transform infrared (FTIR) spectra of the geopolymeric mortars (A) G1R2, (B) G1R3 and (C) G1R4.

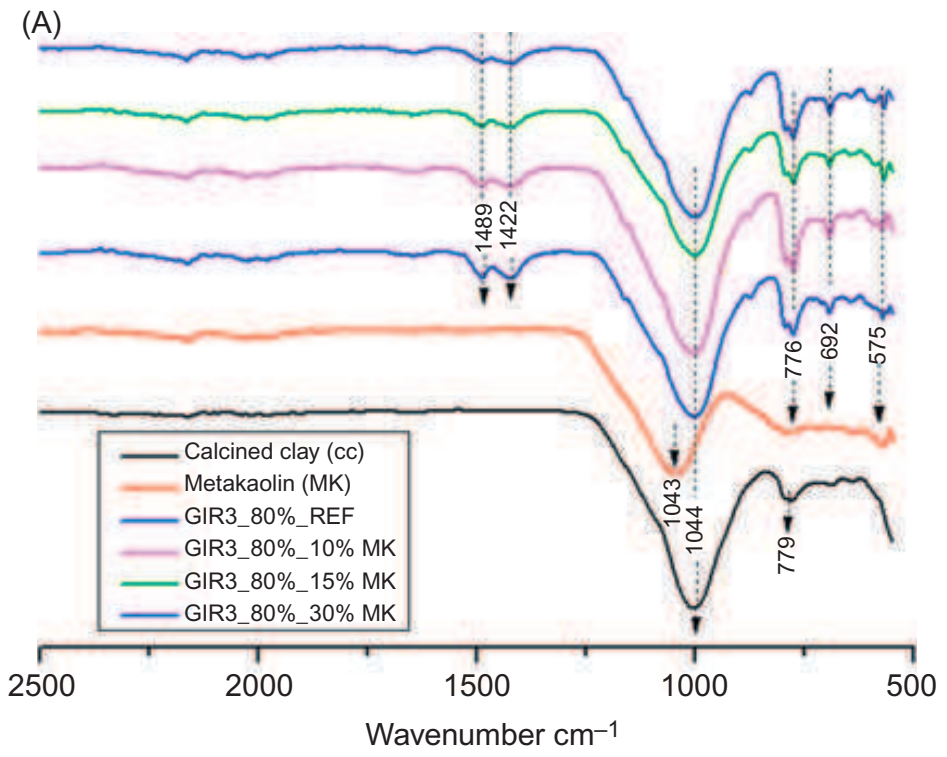

(C)

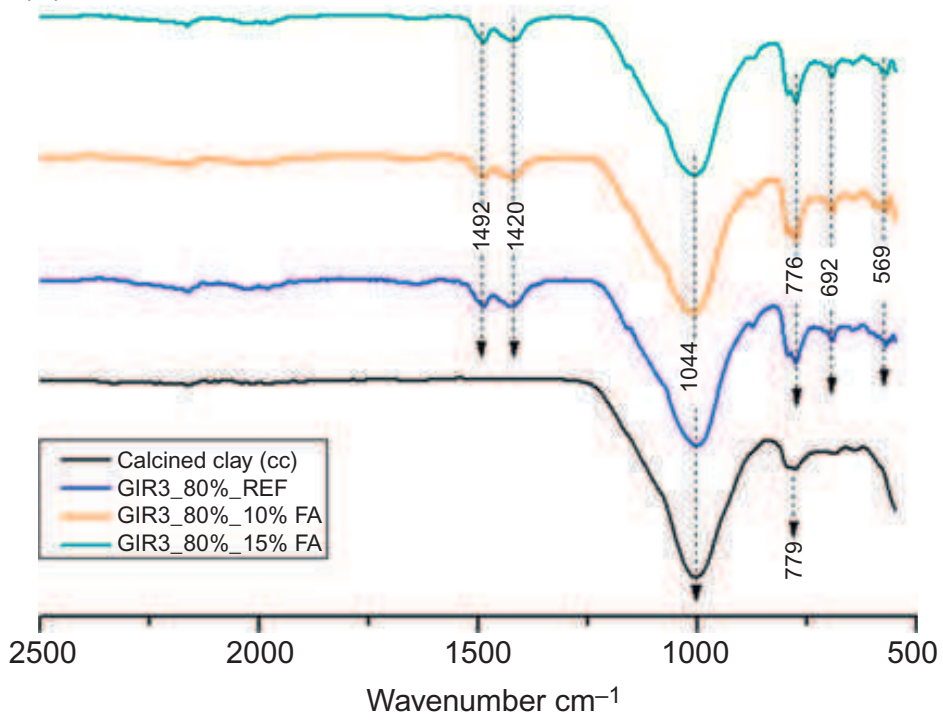

Figure 12.16 Fourier transform infrared (FTIR) spectra of G1R3 modified geopolymeric mixtures: (Above) metakaolin (MK) based; (Below) Fly ash (FA) based. 

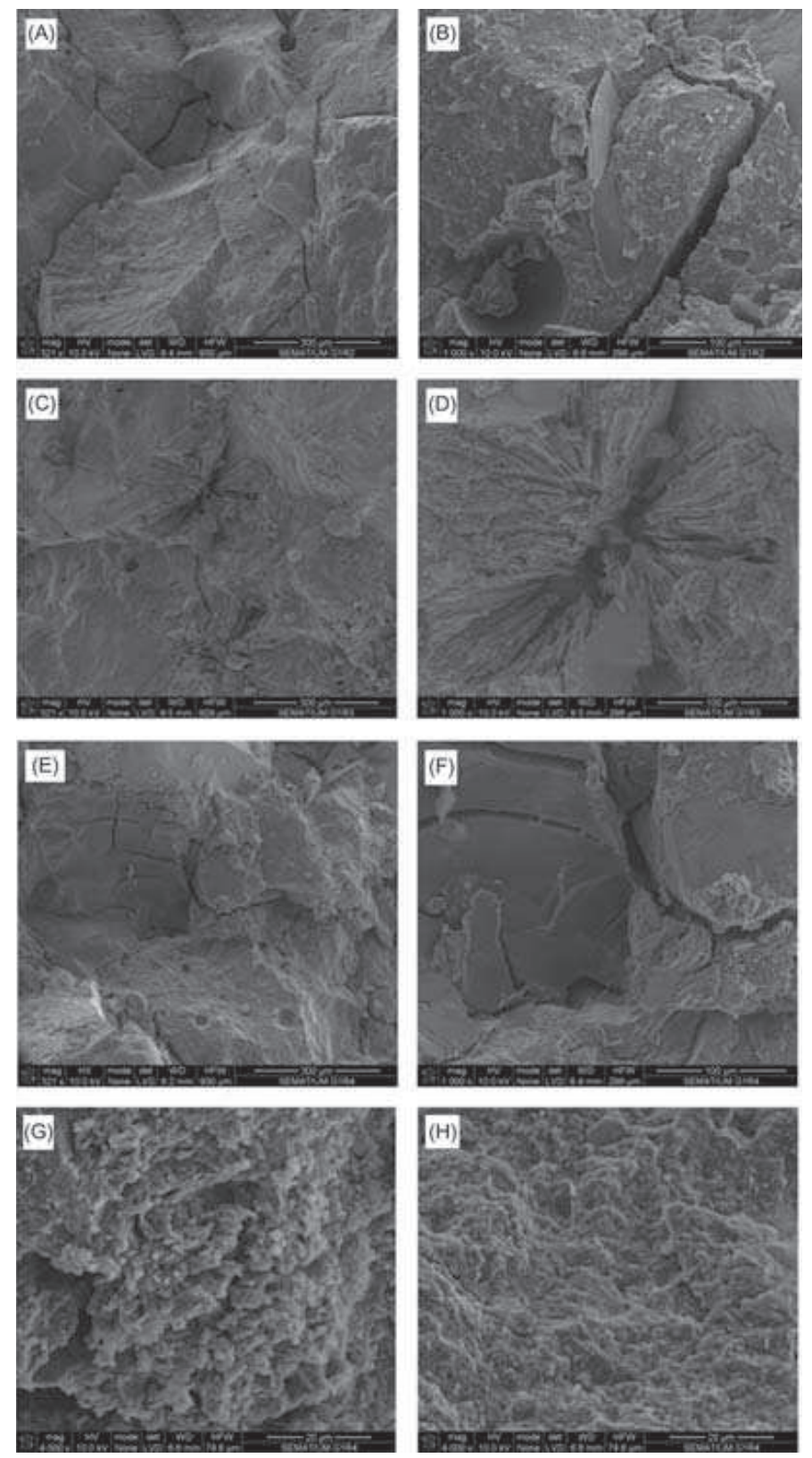

Figure 12.17 SEM micrographs of geopolymeric mortars: G1R2 (A),(B); G1R3 (C),(D); G1R4(E),(F),(G),(H).
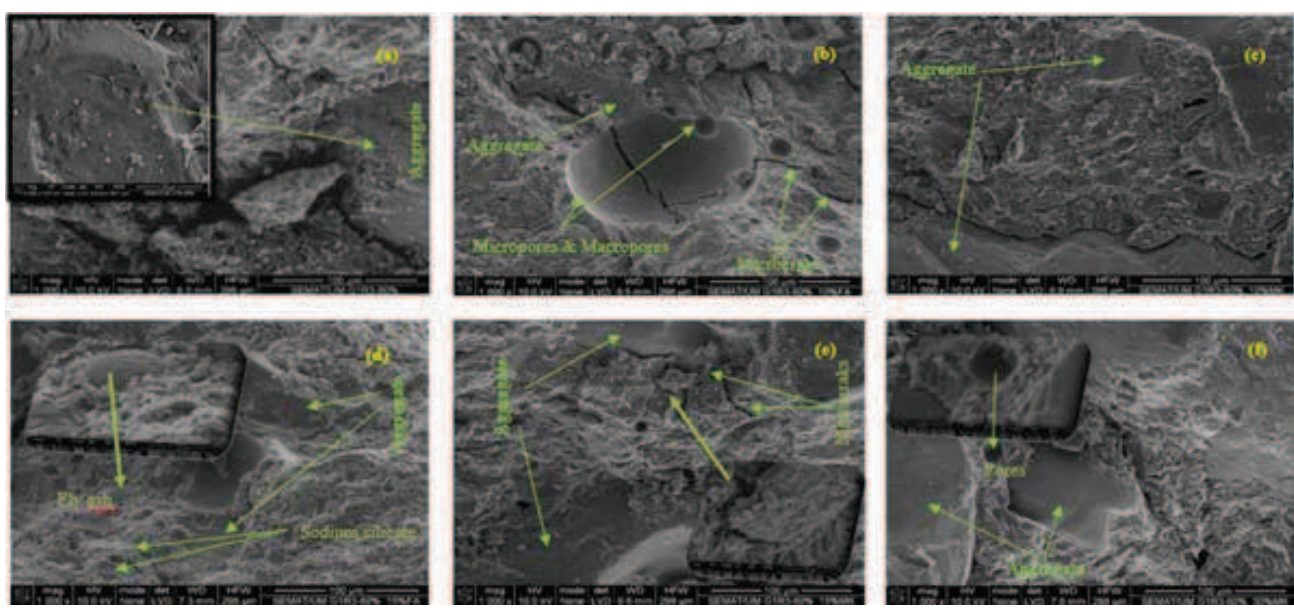

Figure 12.18 SEM images of geopolymeric mortar G1R3-80\% with different (\%) Metakaolin (MK) and fly ash (FA): (A) (G1R3-80\%_ REF); (B) G1R3-80\%-10\%FA; (C) G1R3-80\%-10\%MK; (D) G1R3-80\%-15\% FA; (E) G1R3-80\%-15\% MK;

(F) G1R3-80\%-30\% MK. 
of the mixture with $30 \% \mathrm{MK}$ content (f), which has the lowest shrinkage performance. The SEM analysis also revealed the existence of unreacted elements as aggregates, and some micropores and macropores with different shapes (b) inside the geopolymeric sample. The alkaline solution contacts with the smaller particles housed inside the larger spheres and forms a dense geopolymer matrix: (Photo (d)). Thus, the microstructures in all geopolymer mortar samples confirmed that the crystalline phases are generally nonreactive, and that these are present in the form of inactive fillers as the particle of sand (aggregate). Additionally, the dissolution of FA under the conditions prevailing during geopolymerization is much slower than the dissolution of MK. From these results, it appears that increasing the amount of MK increases the amount of reactive phase.

\subsection{Conclusions and future trends}

This chapter presents some experimental results of an investigation concerning the development of geopolymeric repair mortars based on low reactive Tunisian clay. The following conclusions can made upon it. The mineralogical analysis shows that the Tunisian clay is composed of kaolinite associated to quartz and illite, with minor amounts of gypsum and hematite. The use of a geopolymeric mortar with a binder/ sand ratio of 1:4 meets minimum workability conditions for patch repair using the hand placement technique. The geopolymeric mortar shows a high unrestrained shrinkage behavior. However, the reduction of the alkaline activator/binder mass ratio to $80 \%$ of the former mixtures led to a relevant reduction in the shrinkage performance. The partial replacement of Tunisian clay by FA also leads to a lower shrinkage performance when compared to that of the reference mixture. Partial replacement by MK outperforms FA-based mixtures. The compressive strength at 28 days curing is below typical compressive strength of reinforced concrete structures, although the replacement of the Tunisian clay by $15 \%$ and $30 \% \mathrm{MK}$ allows for compressive strengths of around $30 \mathrm{MPa}$, typical of old PC reinforced concrete structures and constitute an important compressive strength requirement for repair mortars. The modulus of elasticity increases slightly with the replacement of Tunisian clay by FA and in a higher extension when MK is used. The concrete beams repaired with the calcined clay and 30\% MK mortars show a flexural strength around $230 \%$ higher than the plain concrete beams. The hydration products show typical geopolymeric phases. Further investigations regarding compatibility issues are still needed.

\section{References}

Bouaziz, R., Rollet, A.P., 1972. Tome 2 Paris .L'analyse thermique L'examen des processus chimiques. Gautier-Villars.

Brinker, C.J., Scherrer, G.W., 1990. Sol Science. The physics and chemistry of sol-gel processing. Academic Press, San Diego. 
BS EN 1542, 1999. Products and Systems for the Protection and Repair of Concrete Structures. Test Methods. Measurement of Bond Strength by Pull-off, first ed. IPQ, Portugal.

Criado, M., Fernandez-Jimenez, A., Palomo, A., 2007. Alkali activation of fly ash: effect of the $\mathrm{SiO}_{2} / \mathrm{Na}_{2} \mathrm{O}$ ratio: Part I: FTIR study. Microporous Mesoporous Mater. 106 $180-191$.

Concrete Society, 1991.Patch Repair of Reinforced Concrete. Model Specification and Method of Measurement. Concrete Society Technical Report no. 38.

Cusson, D., 2009. Durability of concrete repaired concrete structures. In: Delatte, N. (Ed.), Failure, Distress and Repair of Concrete Structure. Woodhead Publishing Limited, Abington Hall, Cambridge, pp. 297-321.

Duxson, P., Mallicoat, S., Grant, L., Kriven, W., Deventer, J., 2006. The effect of alkali and $\mathrm{Si} / \mathrm{Al}$ ratio on the development of the properties of metakaolin-based geopolymers. Colloids Surf. 292, 8-20.

Duxson, P., Provis, J., Grant, L., Mallicoat, S., Kriven, W., van Deventer, J.S.J., 2005. Understanding the relationship between geopolymer composition, microstructure and mechanical properties. Colloids Surf. 269, 347-358.

Emmons, P., Vaysburd, A., 1994. Factors affecting the durability of concrete repair: the contractor's viewpoint. Constr. Build. Mater. 8, 5-16.

Emmons, P., Vaysburd, A., 1996. Total system concept-necessary for improving the performance of repaired structures. Constr. Build. Mater. 10, 69-75.

EN 1992-1-1, 2004. Eurocode 2: Design of Concrete Structures - Part 1-1: General Rules and Rules for Buildings. 225 p.

Essaidi, N., Samet, B., Baklouti, S., Rossignol, S., 2014. Feasibility of producing geopolymers from two different Tunisian clays before and after calcination at various temperatures. Appl. Clay Sci. 88-89, 221-227.

Kakali, G., Perraki, T., Tsivilis, S., Badogiannis, E., 2001. Thermal treatment of kaolin: the effect of mineralogy on the pozzolanic activity. Appl. Clay Sci. 20 (1-2), 73-80.

Khan, M.I., Almusallam, T.H., Alsayed, S.H., Al-Salloum, Y.A., Almosa, A.A., 2012. Bond characteristics of substrate concrete and repair materials. Concrete Repair, Rehabilitation and Retrofitting III-Proceedings of the 3rd International Conference on Concrete Repair, Rehabilitation and Retrofitting, ICCRRR 2012, pp. 1041-1045.

Lazarer, A.N., 1972. Vibrational Spectra and Structure of silicates. Consultants Bureau, New York/London.

Lee, W.K.W., van Deventer, J.S.J., 2002. The effects of inorganic salt contamination on the strength and durability of geopolymers. Colloids Surf. 211, 115-126, 2002.

Li, C., Sun, H., Li, L., 2010. A review: the comparison between alkali-activated slag $(\mathrm{Si}+\mathrm{Ca})$ and metakaolin $(\mathrm{Si}+\mathrm{Al})$ cements. Cem. Concr. Res. 40, 1341-1349.

Lin, X., et al., 2003. In-situ synthesis of NaY zeolite with coal-based kaolin. J. Nat. Gas Chem. 12, 63-70.

Mackenzie, R.C., 1957. The Differential Thermal Investigation of Clays. Mineralogical Society, London.

Morgan, D., 1996. Compatibility of concrete repair materials and systems. Constr. Build. Mater. 10, 57-67.

Nakamoto, K., 1997. Infrared and Raman Spectra of Inorganic and Coordination Compounds. willey, Chichester.

Pacheco-Torgal, F., Gomes, J., Jalali, S., 2008a. Adhesion characterization of tungsten mine waste geopolymeric binder. Influence of OPC concrete substrate surface treatment. Constr. Build. Mater. 22, 154-161. 
Pacheco-Torgal, F., Gomes, J.P., Jalali, S., 2008b. Investigations on mix design of tungsten mine waste geopolymeric binders. Constr. Build. Mater. 22, 1939-1949.

Pacheco-Torgal, F., Castro-Gomes, J., Jalali, S., 2008c. Properties of tungsten mine waste geopolymeric binder. Constr. Build. Mater. 22, 1201-1211.

Pacheco-Torgal, F., Domingos, M., Ding, Y., Jalali, S., 2011. Composition, strength and workability of alkali-activated metakaolin based mortars. Constr. Build. Mater. 25, 3732-3745.

Pacheco-Torgal, F., Abdollahnejad, Z., Miraldo, S., Baklouti, S., Ding, Y., 2012a. An overview on the potential of geopolymers for concrete infrastructure rehabilitation. Constr. Build. Mater. 36, 1053-1058.

Pacheco-Torgal, F., Fucic, A., Jalali, S., 2012b. Toxicity of Building Materials. Woodhead Publishing Limited, Abington Hall, Cambridge, 512 p.

Pacheco-Torgal, F., Labrincha, J.A., Jalali, S., John, V.M., 2013. Eco-Efficient Concrete. Woodhead Publishing Limited, Abington Hall, Cambridge, 592 p.

Pacheco-Torgal, F., Abdollahnejad, Z., Miraldo, S., Kheradmand, M., 2016. Alkali-activated cement-based binders (AACB) as durable and cost competitive low $\mathrm{CO}_{2}$ binders: some shortcomings that need to be addressed. In: Nazari, A., Sanjayan, J. (Eds.), Handbook of Low Carbon Concrete, first ed., Elsevier Science and Tech, Waltham, pp.195-216.

Phair, J.W., van Deventer, J.S.J., 2002. Effect of the silicate activator pH on the microstructural characteristics of waste-based geopolymers. Int. J. Min. Process. 66 (1-4), $121-143$.

Provis, J.L., 2014. Geopolymers and other alkali activated materials: why, how, and what? Mater. Struct. 47, 11-25.

Teixeira-Pinto, A., 2004. Metakaolin Alkali-Activated Based Binders. PhD Thesis, University of Minho, Portugal.

Van Deventer, J., Provis, J., Duxson, P., Brice, D., 2010. Chemical research and climate change as drivers in the commercial adoption of alkali activated materials. Waste Biomass Valor. 1, 145-155.

Van Deventer, J., Provis, J., Duxson, P., 2012. Technical and commercial progress in the adoption of geopolymer cement. Miner. Eng. 29, 89-104.

Yip, C.K., Lukey, G.C., Deventer, S.J.S., 2005. The coexistence of geopolymeric gel and calcium silicate hydrate gel at the early stage of alkaline activation. Cem. Concr. Res. 35 (9), 1688-1697.

Wang, H., Li, H., Yan, F., 2005. Synthesis and mechanical properties of metakaolin-based geopolymer. Colloids Surf. A: Phys. Chem. Eng. Aspects. 268 (1-3), 1-6.

\section{Further reading}

Davalos, J.F., 2012. Advanced Materials for Civil Infrastructure Rehabilitation and Protection. Seminar at The City College of New York, New York.

Fernandez-Jimenez, A., Palomo, A., 2005. Mid-infrared spectroscopic studies of alkali activated fly ash structure. Microporous Mesoporous. 86, 207-214.

Hollaway, L.C., 2011. Key issues in the use of fibre reinforced polymer (FRP) composites in the rehabilitation and retrofitting of concrete structure. In: Karbhari, V.M., Lee, L.S. (Eds.), Service Life Estimation and Extension of Civil Engineering Structures. Woodhead Publishing Limited, Abington Hall, Cambridge. 